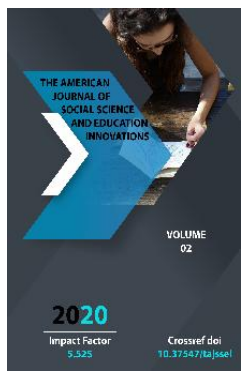

\title{
Economic Activities Of Agriculture And Urban Population Of Zarafshan Oasis In The XIX - XX Centuries
}

Akbar Avaz Ugli Idiyev

Teacher, 34th High School, Tashkent Region, Uzbekistan

Journal Website:

http://usajournalshub.c

om/index,php/tajssei

Copyright: Original

content from this work may be used under the terms of the creative commons attributes 4.0 licence.

\section{ABSTRACT}

In the Zarafshan oasis, along with the ethnic groups mentioned by our researchers, there are also ethnic groups that are not yet listed. This paper provides a brief overview of their habitats and the economic activities of their inhabitants. It has also been analyzed on the basis of various sources and scientific literature and studied from the point of view of the XIX-XX centuries.

\section{KEYWORDS}

Source, ethnos, ethnic group, research, economy, work, rural population, urban economy, Zarafshan, agriculture, silkworm breeding, handicrafts.

\section{INTRODUCTION}

"The restoration of the huge priceless spiritual and cultural heritage created by our ancestors over the centuries from the first days of our independence has become an extremely important task that has risen to the level of state policy". During the years of independence, significant research work has been carried out in the field of studying the 
history of our country. The new concept of the history of Uzbekistan provides for an objective study of history based on concrete evidence, based on written sources. The study of the political and economic situation of the population of the Central Zarafshan oasis is also an urgent task. These include the sociopolitical, economic and cultural life of the Central Zarafshan oasis at the beginning of the XIX-XX centuries under the rule of the Bukhara Emirate and within the colonial system of the Russian Empire. The need to study this research object as a separate topic is determined by the following. It occupies a special place in the socio-political and economic life of the Bukhara Emirate of the Middle Zarafshan oasis: As one of the leading and richest regions of the Turkestan Governor-General's Office, this region has all the features of the colonial period. The ethnic composition of the population of the Central Zarafshan oasis is diverse. These features fully reflect the fundamental social, economic and political situation of the emirate and the colonial period.

\section{The Main Results And Findings}

If we divide the territory of the Zarafshan oasis, we will see that several ethnic groups live in each region. There are similarities and differences between the ethnic composition of each of them and their economic activities.

1. Bulung'ur district. There are 12 ethnic groups of our people in the district. These are: forty ungulates (branches: chubot, watchtam, changal, mirzaesa, mullaesa), Chinese (hammer, erganakly (1), Karakalpak, Turkmen, Mongolian, vakkos, naiman, Kyrgyz, Urai, Mangit, Tajik. For the first time, hoofed and ungulate names were recorded from these ethnic groups.
2. Jomboy district. It was revealed that there are twenty ethnic groups of the Uzbek people in this district. These are: salin, chinese, ungulate, kipchak, bakhrin, palace, chinese, mangit, karakalpak, kangli, kazakh, forty (s), kiyat, naiman, turkmen, rib, bek, khodja, thousand, robber. Apparently, in addition to the seed names found in other publications, the list also includes seed names such as hooves, ribs, and carp.These are: solin, chinese, ungulate, kipchak, bakhrin, palace, china, mangit, karakalpak, kangli, kazakh, forty (s), kiyat, naiman, turkmen, ribs, bek, khoja, min. Apparently, in addition to seed names found in other literature, the list also includes seed names such as hooves, ribs, and carp.

3. Ishtikhon district. Twenty ethnic groups of Uzbeks have been identified in the district. These are: turkmen (2), chinese, mitan (3), muitan, barlos, bek, alpine, ojorik, tuvadok, karakalpak, iranian, arabic, georgian, eshon (khoja), takchi, naiman, jovi, kanjigali. (branches: toshim, hasankori, nurim, alakai, hammer, beshbola, itburboy, boytopi, oytamgali) (4), artilleryman. Some ethnic groups are listed for the first time. These are: alpine, ojdzhorik, tuvadok, georgi, takchi, treadmill.

4. Kattakurgan district. Nineteen ethnic groups live here. These are: mangit, naiman, kipchak, min, modrai, dukchi, qiyat, almasuvon, jalair, khoja, turkmen, beks, saroy, bahrin, kanjigali (branches: nurim, oytamgali), garluk, bekto 'pi, arab, ejilar. Of these, modray, dukchi, almasuvon, ejji are not mentioned in other sources.

5. Narpay district. Seven ethnic groups have been identified in the district. These are: kipchak, chinese, naiman, mangit, olchin, karakhitian, khoja. 
6. Nurobod district. Research has shown that there are thirteen ethnic groups in our district. These are: naiman, juz, saray, khoja, smell, turk-barlos (5), mangit, china, bakhrin, uishun, harduri, kiyat. The name of the Harduri clan does not appear in any of the abyss.

7. Akdaryo district. There are fifteen ethnic groups in the district. These are: naimansky, chinese, kipchak, sarihitoi, eshan, khoja, otarchi, kungrad, tugai, kirk, barlos, min, said, chinese (kipchak), turkmen. For the first time, we have registered the names of Sarikhitay and Tugay seeds from the mentioned seeds.

8. Payariq district. Thirty-three ethnic groups are listed here, namely: Kiira (6), Corp (6), Junniboy (6), Kupoy (6), Oltibek (6), Chortkesar, Adinasari, Bagdonli (Okat), Min, Mang'it (Karamang 'Mangsur Dog), barlos, chigot, sarypchak, toma, ungulate, khoja, turkmen, chandir, akchob, bell, kipchak, beklar, naiman, forty, bakhrin, eagle, yovbosar, tugolto $p$, tobonlik, oytamgali, bogadzhinli, boshmak, culton. These include seeds such as kyra, bed, dzhunniboy, kupoyi, altibek, akchob, chigot, hoofed, yovbosar, tokoltop, tobonlik, bogadzhinli, boshmak, bagdonli, chortkesar, adinasari. names are published for the first time.

9. Pastdargom district. Observations show that there are sixteen tribes of our people in the district. These are: Nayman (7), Mangit (8), Arabic (9), Iranian, Kipchak, Khoja, Sarai (branches: Tugboysaroy, Okrachsaroy, Shamosaroy, Qingirsaray, Kipchaksaroy, Beksaroy), chuyut, chinese, juz (yuz), altai, kazakh, bayraguz, burqut, turkman, chandir (10). Of these, the Altai and the flags were registered for the first time. Although the Arab origins go back to the Arabs, they are now part of the Uzbek people.
10. Pakhtachi district. There were six ethnic groups in the district. These are: bahrin, qirqigit, nayman, sarai, chinese-kipchak, mangit. For the first time in the history of the scientific community, the seed of the forty is appearing among them.

11. Samarkand district. Five ethnic groups were registered in this district. These ethnic groups are: nayman, arab, iranian, burkut, turkmen.

12. Taylak district. Nineteen ethnic groups of the Uzbek people met in the district. These are: nayman, barlos, ming, hoofed, mogul, multani, mazangi, kuchchi, palace, bahrin, yuz, jalair, alpomish, toshurug, temur, beks, changallar, kyrk, kallar. Apparently, among the clans found in many sources, there are some that were registered for the first time: hoofed, mullein, mazangi, alpomish, stone seed, timur, changlalar, kallar.

13. Urgut district. Twenty-nine ethnic groups have been identified in the district. These are: nayman (branches: ukrachnayman, collar, jondiznayman, dark), kuchchi, mogul, hoofed, bahrin, kenagas, turkbarlos, uyshun, winter, barlos, galcha, on, turk, slaves, kipchak , uyghur, tora, navruz, baghlan, khoja, akhchalar, yuz (juz), plural, karapachak, mingiya, tajiktop, eshon $[1,46]$. Among them are ungulates, torahs, navruzs, slaves, akhchas, kopts, and karapaks.

14. Qoshrabat district. Observations have led to the conclusion that there are seventyfour named ethnic groups in the district. Here they are: blackberry, bell, quarter, olay, dervish, itai, altibek, kanchigali, oytamgali, koshtamgali, bogadzhili, kurjintubi, forty (s), eshmat, kazoyogli, hudoinazar, arbaki, sultani, tabagdi, rassolay, sootu, mixayam, uxum, ovush, chingiz, tentak, saroy, rich churoch, barlos, almasuvon, hammer, jobitopi 
(yobi), bektop, tulkitop, kaltop, chungari, metantop, mangit, turkman, bahrin, jilotamgali, altiziqoziyoqqiyot, karakhaniy , chimmoz, borqut, sirsulov, baroq, kilicheva, berkut, bozchi, mayakchi, kuyuzgun, oboytush, china, arbobtop. Other than seeds such as bell, kanjigali, oytamgali, koshtamgali, forty, palace, bek, kalmak, barlos, yobi, mangit, turkmen, bahrin, kiyat, velvet, china observed for the first time.

Apparently, in the literature we observed, seeds and their branches were found in 373 names, and as a result of our direct conversations with informants, in addition to them, 87 more names of seeds and their branches were identified. So far, our research proves that the oasis has a total of 460 seeds and their branches. This is certainly not the last frontier, as communication with each new informant shows that there are more seed names than that [4, 42]. Apparently, in the literature we observed, seeds and their branches were found in 370 names, and as a result of our direct conversations with informants, an additional 90 names of seeds and their branches were identified. So far, our research proves that our nation has a total of 463 seeds and their branches. This is certainly not the last frontier, as communication with each new informant indicates that there are newer seed names. So, this kind of research is, firstly, very important in determining the names of ethnic groups that are still unknown to science, and secondly, it is very relevant in the study of the ethnogenesis of the Uzbek people. At the same time, the geography of the distribution of ethnic groups is very different. Some of them have a wide geography, while others are narrow. There are ethnic groups that live in 3-4 or even 14 districts, while another group lives in only 1 or 2 districts. The urban population was also ethnically similar, and economic activities were closely intertwined. [6, 63-64].

There were several directions in the economic life of the city. First, of course, crafts and their industries, secondly, the cultivation of agricultural products, which have a place in the life of the urban population, and thirdly, trade relations. Based on the analysis of these territories, one can describe the economic life of the city. Samarkand is a developed medieval city in its main appearance. This is evidenced by the construction sites, the lifestyle of the population, the concentration of many large and property in the city itself. Not only is trade flourishing in the city, but so is education. Madrassas played a key role in this. In general, Destroyed by wars and looting in the first half of the XIX century, the city gradually regained its economic, political and cultural status in the relatively stable political situation of the period under study. Until the first half of the 19th century, the population of Samarkand was mainly engaged in agriculture, while the majority of the city's population was engaged in handicrafts and trade. During this period, the city was considered one of the largest centers of handicrafts in Central Asia. For example, in the middle of the XIX century in the city there were 681 weavers, 200 saddlers, 40 manufacturers of paper and paper products, 36 ironworkers, 34 manufacturers of silk products, 30 manufacturers of leather goods, 15 silk spinners, according to official sources, there were 15 painting workshops. Apparently, weaving was the most developed field. Indeed, Samarkand artisans have made a variety of silk, semi-silk and cotton fabrics. These include alacha, hosa (thin semi-silk fabric), pencil (cotton fabric type), chit, kanaviz, gray, beqasam, tivitli turban, silk and semi-silk carpets, dop pilar, etc. [6, 72]. It should be noted that the wide range of 
products in the field of handicrafts and textiles, and the demand for products in this field was high in all societies. It was a natural process for this industry to develop, especially in Central Asia, where cotton and silk are widely grown, including in Samarkand. However, we must also note that some textile products grown in Samarkand were in great demand not only in the region but also in other countries. For example, in a statement issued by a correspondent of the "Novoyevremya" newspaper at the Turkestan Exhibition of Agriculture and Industry, which opened in Tashkent in 1878, it was stated that "many high-quality, colorful silks were sent from Samarkand, and these fabrics competed with textiles made in Bukhara and many other cities of Turkestan." According to O.A. Sukhareva, alacha was originally made by Samarkand artisans and was mainly woven by Tajiks. [2, 54]. According to some reports, they were brought from Bukhara, and according to other sources, from Khojand. According to OASukhareva, Uzbeks and Tajiks living in the neighboring guzars, known as Yomini and Zomini, were engaged in weaving a fabric made from a local yarn known as pencil, usually with blue and white stripes. These guzars were a group of people who migrated from Yam and from Zaamin. According to P.I. Pashino, the labor of domestic workers was widely used in the production of handicrafts in Turkestan, "...In the production of paper, one industrialist gins cotton to one family, spins to another, sews to a third, dyes to a fourth, and so on. distributed works. This, in turn, relieved him of the obligation to prepare space for workshops, purchase machine tools, and pay workers when they were not working ... " A similar situation is observed in Samarkand. In some cases, most of the work is done by women and children. They cleaned cotton, processed fabrics, wrapped yarn, and so on. In Zarafshan district, silk ipasosan was "produced by Tajik and Iranian women with the help of charkh, while Uzbek and Kyrgyz women made it with urchuk. A woman could spin 2 to 4 pounds of silk or wool a year using this equipment" [7, 47]. Many women have developed these products for their own needs and for sale. However, many artisan and home-based families are in financial difficulties and live on low incomes. This was due to the fact that not all weavers had shops and were not able to sell their products directly in the market. Many weavers sold their products with the help of sellers. They had to pay 30\% less for the product. This meant that the weavers had to take money from the sellers and sell the product at a low price if they did not have the funds before production. [2, 69]. In the first half of the XIX century, Samarkand had 63 adras weaving looms and 41 hemp weaving looms, which were collected by fortyfive people. In addition to Uzbeks and Tajiks, some Jews from Samarkand were also involved in hemp production. [8, 74-75]. In general, production in Samarkand was smallscale handicrafts. Men were more involved in sewing. In Samarkand, there are a number of workshops where several masters work on separate sewing machines, where “... only special silk and high-quality fabrics are used, which are used for demanding robes, turbans and belts." According to the archives, "In Samarkand, there were few specialized workshops for cleaning silk or wool. Because refined silk or locals in need of it bought and cleaned it in their own homes. Those who specialized in this trade worked as contract tailors and rarely brought refined wool and the like to the market". The textile industry is mainly divided into types depending on the products made from local products. One such industry was silkworm breeding and the production of silk products. It is estimated that in the first half of the 19th century, about 400 farms were engaged in the cultivation of 
silk products. Each farm produced between 5 and 1.5 pounds of produce. Silk raw materials were also brought to the city from neighboring areas. In Samarkand, hand-made knives were used to process silk.

Most artisans make their own silk processing equipment. Silk was made by Samarkand craftsmen from a variety of products. At one time, Samarkand was the largest producer of silk products in the country and the UAE's largest silk products were sold in its markets. Canaus is made of silk fabrics, beqasam and adras are made of semi-silk fabrics [3, 532533]. In the first half of the XIX century in Samarkand, along with the production of fabrics, the field of dyeing fabrics was well developed. There were special masters in painting. Special blue paints are made in Samarkand. There were also specialty stores that produced paint throughout the year. In general, there were special masters in the preparation of paints, and masters in the field of painting. In the dyeing workshop, paints are always paid for and the fabric is dyed in front of the customer and returned to the owner without being dried. Wages were charged depending on the quality of the dye and the size of the fabric. Depending on the quality of the dye, a 2.5 pound (1 pound equals 570 grams) fabric dye is priced at 40 to 60 cents. It is said that in the 19th century, local Jews from Samarkand were mainly engaged in dyeing cubic silk.

Samarkand masters were able to make different colors of paints. The Jews were famous for making Nile paint. Metalworking is one of the main industries in the city. During the war, the industry specialized in the production of military equipment, and at other times in the production of various metal products: knives, carpentry and craft tools, and so on. . During the war, the industry specialized in the production of military equipment, and at other times in the production of various metal products: knives, carpentry and craft tools, and so on.

Samarkand masters made products from copper, brass, cast iron, iron and various alloys. A unique school of blacksmithing was formed. They have their own metalworking techniques. The cast iron is mainly used for making pots, as well as household items and tools. Some types of trades have achieved a certain specialization. Blacksmiths usually specialize in several types of products: some only made horseshoes for horses and donkeys, others only made lathes and carpentry tools. Most of the iron products are made of iron imported from Russia $[1,56]$. N.A Kirpichnikov classifies blacksmith products into three groups:

Manufacturing of gates, nails, horseshoes, washers, car wheels, rings, shovels. Manufacture of tools for masons, chisels, sickles and chisels, tools for carpenters. Blacksmithing of knives, scissors, saws, chisels and similar small tools. Among the trades of Samarkand, the Tatars also played an important role. The products made by them are of high quality. The leather industry was considered one of the main branches of handicraft production until the region was incorporated into the territory of the Russian Empire. Because leather and leather products play an important role in people's lives. In addition, the products of this sector have played a key role in regional and regional trade in general. There is also a tannery in the city called Charmgaron [2, 61]. Paper production is developed in Samarkand, among other professions. In the XV-XIX centuries Samarkand was a major center of paper production. Cannabis yarn made from cannabis used to make paper was used as a 
raw material. They were dispersed, scraped and soaked in lime water overnight. Thus, the raw material was processed for at least a week and then the paper was prepared. Samarkand paper is made in different colors. According to PP Ivanov, the production of writing paper is widely developed in the city. Paper-making workshops produce paper raw materials and writing paper separately. In some cases, these products are made in separate workshops and sold. The final processing of the paper was carried out by a specialist - "murakash". In 1869, there were 16 paper mills in Samarkand. At the end of the 18th century and the beginning of the 19th century, the paper industry in Samarkand experienced a crisis. This is due, first of all, to the migration of people to relatively peaceful lands, tired of the wars in the Bukhara Emirate, the looting of nomadic peoples, and the fact that most of the paper masters went to the territory of the Kokand Khanate. Second, the import of large quantities of paper products from Russia in the 19th century also contributed to some extent to the crisis of local papermakers. According to researchers, among the many manuscripts of the XIX century kept in the funds of the Institute of Oriental Studies of the Uzbekistan Academy of Sciences, not a single one was written on Samarkand paper. [4, 10]. This indicates that paper production in Samarkand stopped in the early 19th century. According to another source, "Samarkand paper production was completed in the early 19th century. That is why the places where the paper workshops were located were completely covered with flour mills and grinders. " During this period, Samarkand experienced a crisis not only in paper production, but also in many other industries, as a result of feudal strife, relentless looting, the decline of trade due to insecure trade routes, and the increase in taxes during the struggle. According to A. Vamberi, Samarkand paper is made of "New silk..."[5, 211], According to Pashino who traveled through Central Asia in 1866, the paper is made of cotton, and A. Semyonov argues that old rags and cotton fibers, silk and hemp were also used in the production of paper. It should be noted that the raw materials available in the environment are widely used in the manufacture of any product. Therefore, it can be said that Samarkand artisans of the 19th century made extensive use of hemp, reeds, cotton, flax and silk in the production of paper. [6, 93-97], is reasonable. Samarkand paper had its own watermark. This symbol was a unique seal of the master Mir Ibrahim in the XVI century. This symbol has remained as a symbol of Samarkand paper until recently and is called "Mir-lbrokhim". According to the raw material of Samarkand paper, it is mainly divided into three grades. One of them is made of silk, tarandi and does not contain any cotton fiber. The paper is very neat, beautiful, soft and shiny yellow.

This paper is called "abrishum paper" or "silk paper". The second type of Samarkand paper is semi-semi-paper, which is made by adding an equal amount of cannabis stems to raw silk. The paper, called "Nimkatoni", was thick, neat and well-dried, making it easy to turn the pages of a book made from such paper. The third grade paper was almost pure cotton and was slightly inferior to the above papers in quality and preparation method. [4, 46-47]. The main workplaces of the paper mills operating around Samarkand were private or foundation workshops. In the process of making the paper, the division of labor was practiced among the masters working in the workshop. For example, master of paper making is a paper-cutter, cotton washer, cotton picker, paper and flour additive, paper hanger or wall hanger. called master paper 
chaspon. In addition, in the trench there were a paper kicker, an obyuvoz user, several halfs and students. Paper words were sold here to traders, calligraphers and other people in need of paper. Paper traders sold the paper to nearby cities or distant lands. Due to the disappearance of the ancient method of making paper, A. Fayziev gives the following information about how our ancestors made paper on the basis of documents found in the archives and other sources: The required amount of first grade cotton was obtained, rinsed thoroughly with water on the neck raust, and then it was weighed overnight in an objuvoz. The talc was then rinsed a second time in water, mixed with the required amount of alkali and lime, mixed well, and weighed a second time in an objuvoz. The required amount of recycled paper talc was mixed with 4 poods of alkali and 1 podahakar on a mat for 3 days in summer and 15 days in winter. [10, 78]. After the expiration of the specified period, the paper talc was placed in the objuvoz for the third time and weighed for 8 days. The talc in the objuvoz was then removed, surpmatogased, and rinsed in water. Heavy stones were used to squeeze the water out of the paper talc. The waterheated paper talc was placed in the objuvoz for the fourth time and weighed in 10 days. Only after these processes is the dough, which is needed for making paper, placed in a special trench, kicked with a foot for 2 hours, and then beaten with a stick for 2 hours. Then water was added to make it liquid. The liquid paper pulp is spread evenly on a fine grater made of horseradish [11, 102-104]. In this process, special attention was paid to the thickness of the paper, as it was determined by how thick or thin it was, and a stone was pressed over it to squeeze out the water overnight. Thinly sliced into large, thin sheets of paper, the wheat flour and shea butter were squeezed and dried for 3 hours in the summer and glued to the walls of a special room overnight in the winter or hung on a pole made of wire. The dried leaves were removed from the wall and cut to the required size with a special knife. The syrup is then applied to both sides of the sheet. The paper was treated with stone to make it more dense and shiny. This process is repeated two or three times as needed. The paper was hung on a string to dry completely and then consumed $[12,73]$. According to the archives, 18,720 sheets of paper were used to make 24 pounds of American cotton, 24 pounds, 6 pounds of lime, 10 pounds, more than 1 pound of oil, 6 pieces of cloth (1 piece was 6-7 feet long). ) was used. Paper words also pay special attention to what color it is in the process of making paper. The color of the sheets meant a lot. For example, bluemourning, a sign of separation, light-red - the message of happiness, joy, celebration. Blue papers were mainly used to convey sad news. Paper bulls often dyed the paper bright red and green, because these colors give a person more mental freshness, peace of mind and prevent fatigue than white paper. $[13,67]$.

\section{CONCLUSION}

The sources contain a lot of information about oil mills, mills and water mills of the Central Zarafshan oasis. Most of them run on water and produce cheap and quality flour, rice. As a result, the number of such mills and ponds increased throughout the XIX century. The reason for this was the abundance of water here and the abundance of grain crops in the fields. In the early XIX-XX centuries, the cities of Samarkand, Kattakurgan, Dahbed, Yangikurgan, and Peyshanbe, which were the economic and cultural centers of the Central Zarafshan oasis, existed. In these cities, trade is of particular importance. The ethnic composition of the city's population changed 
in the late 19th century. The inflow of Russian capital, as well as the opening of enterprises by foreign entrepreneurs, takes place in the cities. As a result, the ethnic and social composition of the city's population has changed.

\section{REFERENCES}

1. Tashev X. "On the question of the composition of the rural population of the Zarafshan valley", T., 1965. - 245 p.

2. 2.Fayziev A.F. History of Samarkand in the first half of the 19th century (textbook). Samarkand, 1992 .- 254 p.

3. 3.Uzbek Council Encyclopedias, 9-volume. T., 1977, - 667 p.

4. Habibullaev N. Paper production in Central Asia. - T .: Fan, 1992. - 110 p.

5. Vambery A. Journey through Central Asia. - SPb., 1855 .-- 311 p.

6. Qilichev R.. A good paper in the world will come out of Samarkand... // Lower Zarafshan oasis: history of social, cultural, spiritual life (second book). - Tashkent: Fan, 2007. - 297 p.

7. 7.Bartold V.V. "The Turks. Twelve lectures on the history of the Turkish peoples of Central Asia "// Soch. T. V. - M., 1963 .-$346 \mathrm{p}$.

8. 8.Bromley Yu. V. "Essays of the theory of ethnos", - Moscow: Nauka, 1983. - 426 p.

9. Bromley Yu.V. "Contemporary problems of ethnography". -M., 1981. - 472 p.

10. 10.Ziyaev Kh.Z, Lunin B.V "Ethongraphic study of the life and culture of the Uzbeks." - T., 1972 .-- 364 p.

11. 11.Karmysheva B.Kh. "Essays on the ethnic history of the southern regions of Tajikistan and Uzbekistan". - M., 1976 .$372 \mathrm{p}$.

12. History of the peoples of Uzbekistan. T. I. - T., Fan, 1967 .-- 458 p.
13. 13.Polyakov S.P. "Historical ethnography of Central Asia and Kazakhstan. - M., 1980 . - $462 \mathrm{p}$.

14. Rasuljanovna, I. N., \& Rakhmonqulovich, K. N. (2020). Trade Relations Between Ancient Bacteria And China On The II-I BC. The American Journal of Social Science and Education Innovations, 2(07), 47-51. 